\title{
Avoidable Blindness: A World Problem
}

\author{
William Rowland \\ Director, South African \\ National Council for the Blind
}

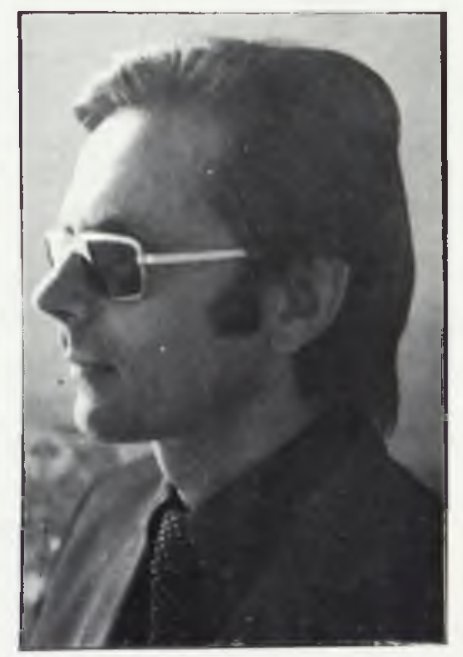

OPSOMMING

Daar is vier biljoen mense in die wêreld. Veertig miljoen van hulle is blind. As die verhouding tussen bevolkingsaanwas en blindheid nie verminder nie, sal die syfer teen die einde van die eeu verdubbel wees.

Ten minste $80 \%$ van die wêreld se blindheid kom voor in die ontwikkelende lande van Asië, Afrika en Latyns-Amerika. Die Internasionale Agentskap vir die Voorkoming van Blindheid (I.A.V.B.) het vasgestel dat daar vier hoofoorsake van blindheid is wat voorkeur in die wêreldgesondheidsprogramme moet kry, $\mathrm{nl}$. tragoom, katarak, onchocercis en bindvliesdorheid.

Voorkombare blindheid is die omvattende term wat gemaak is om sowel voorkombare as genesende blindheid te dek.

Die werk begin met 'n opname van gemeenskappe, mobilisasie van middele, 'n tydperk van konsolidasie en uiteindelik toesig.

Dit is gebiedend noodsaaklik dat oogversorging as integrerende deel van primêre gesondheidsorg beskou moet word en dat die werk van die S.A. Nasionale Raad vir Blindes, gesondheidsowerhede en die versorgende beroepe beter koördineer word om hegter spanwerk te lewer.

$\mathbf{T}$

HERE are four billion people in the world. Forty million of them are blind. If the link between population growth and blindness is not broken, the number will double by the turn of the century.

The International Agency for the Prevention of Blindness (IAPB) was established in 1975 under the auspices of the World Health Organisation. Its task is to co-ordinate the efforts of international ophthalmic organisations, national governments, and blind welfare bodies to combat blinding eye disease.

The First General Assembly of IAPB was held in Oxford. England, from 6 to 8 July 1978, and the present article is a reflection of the proceedings. Attending this conference were 282 delegates from 45 countries. including 2 delegates from South Africa. 


\section{MAJOR CAUSES OF BLINDNESS}

At least $80 \%$ of the world's blindness occurs in the developing countries of Asia. Africa. and Latin America. IAPB has identified four major causes of blindness which are to receive priority in world health programmes

(1) Trachoma: Perhaps 1 in 8 persons in the world suffers from trachoma. which. if left untreated in severe cases. leads to blindness. The highest incidence is found in the Middle East. where seven million people are needlessly blind.

(2) Cataract: In many communities there exists an enormous backlog of cataract cases. According to IAPB est 1 mates. in India alone five million villagers could be given their sight in an operation lasting three minutes and costing five dollars, if only the resources were available.

(3) Onchocerciasis ("River Blindness"): Because of onchocerciasis. the normal expectation for many West African villagers is blindness, not sight. In some communities the sight of $80 \%$ of the population is affected. Already two million people in Africa have gone blind from this disease and the number will continue to grow until the simulium fly has been eradicated.

(4) Xerophthalmia: The most tragic cause of blindness is malnutrition in young children resulting from a deficiency of vitamin $\mathrm{A}$ in their diet. Each year, it is estimated. 250000 children in Asia and Latin America lose their sight from this cause. Remembering that the chances of a blind child receiving schooling are currently only 1 in 40 , and that the chances of a schoolleaver finding a job are only $\mathrm{I}$ in 30 , the plight of children surviving malnutrition is pitiable. And yet the technology exists to prevent this type of blindness through the mass distribution of vitamin A capsules at a cost of just 15 cents per child per year. Other means of prevention are the fortification of sugar with vitamin A and the education of mothers to feed their children a handful of green vegetables every day.

While the picture we have described is grim enough, the Oxford Assembly of IAPB was given an ominous warning: the increasing life expectancy in developing countries will inevitably lead to an increase in the eye problems associated with old age. Therefore, in the years ahead such diseases as glaucoma, senile macular degeneration, and diabetic retinopathy are likely to emerge as new major causes of blindness in the developing world.

\section{AVOIDABLE BLINDNESS}

This is the comprehensive term which has been coined to cover both preventable blindness and remediable blindness. The President of IAPB. Sir John Wilson. has observed that people do not go blind in millions, but individually. Each person losing his sight faces his own special predicament. We must get away from statistics and rather imagine to ourselves an old man in India whose view of his native hills has grown dim with age. or a young West African lad who has to feel his way to the river along a hemp rope, or a babe in arms in some rural village where there is not enough to eat. By emphasising the human element it is hoped that it may be possible to create among nations the political will to eliminate avoidable blindness.

In practical terms, work in any particular region of the world should begin with a survey of selected whole communities to determine the local prevalence of eye disease of all types. Then follows the mobilisation of the necessary resources leading to the launching of an appropriate programme of action. Treatment should not be of a single disease category. but of all eye disease in a community. It has to be stressed that any eye care programme should form part of a primary rural health care programme and fit in with other national health care priorities, such as immunisation. nutrition. etc. The community's own manpower should be utilised, the aim being to make each community self-reliant. Treatment should be family-based.

Once the initial phase of attack in a community is over, there follows a period of consolidation. and. finally. a period of surveillance to ensure that eye disease remains under control. Teamwork between professionals from many different disciplines is essential, including ophthalmologists, epidemiologists, nutritionists, and public health experts. Currently, there is much support for the suggestion that a completely new field of interdisciplinary study should be established to be known as preventive ophthalmology. But even more important, technicians and field workers need to be trained on an unprecedented scale and centres to cope with this demand will have to be brought into being. Of course. vast sums of money will be required. Already a number of international eye foundations are sponsoring IAPB programmes. while there are encouraging indications that the industrialised countries. particularly the United States, may soon be contributing far more liberally towards the work of IAPB

The justification for all these efforts lies in the fact that at least $80 \%$ of the world's blindness is avoidable.

\section{SOME NOTES ON TRACHOMA}

A notable part of the IAPB conference in Oxford was a seminar on trachoma. While trachoma is rightly regarded as one of the major causes of blindness, it is also recognised that this disease is eminently treatable and that it can be eradicated.

Trachoma occurs as an infection of the conjunctiva caused by a strain of minute organisms known as Chlamydia trachomatis. Frequently, the Chlamydial infection is associated with a secondary bacterial infection causing acute ophthalmia. Conjunctival inflammation recurring over many years produces the puckering of the eyelids (entropion) and the inward turning of the eyelashes (trichiasis). It is the scouring action of the eyelashes upon the cornea which eventually leads to blindness. 
Whole families and virtually complete communities may become infected, with contagion spreading through direct contact, the wiping of children"s eyes with a contaminated cloth, and flies. The reservoir of the disease is in preschool children, but blindness ustually occurs in old age after a lifetime of intermittent infection.

Trachoma may be mild or severe and does not always threaten eyesight. The introduction of a programme of treatment into any region should. therefore, be preceded by a survey to identify communities at risk. To do so it is not enough simply to record the general incidence of trachoma, but distinct data has to be collected with regard to all of the following: (1) the incidence of conjunctivitis, (2) the incidence of entropion and trichiasis, and (3) the incidence of corneal blindness. Only in this way does it become clear which communities are endangered.

Once the at-risk communities have been identified. a programme of chemotherapy and surgery is instituted. The pattern of treatment recommended by the World Health Organisation is the application of anti-microbial drugs (tetracycline or erythromycin eye ointment) five times a day for one week each month. This is continued for one year, after which a watch is kept to detect recrudescence. Treatment must be family-based and utilise community manpower resources. Treatment at schools is suboptimal. A key concept in combating trachoma is to reduce the pressure of transmission. This is related to the number of people in a family or community having the disease, and their living conditions. Treatment is unlikely to produce lasting benefits if unaccompanied by improved sanitation and personal hygiene. for example, the regular digging of new pits to dispose of faeces and the provision of running water. Close co-operation between organisations rendering eye services and public health authorities is, therefore, essential, with the eye care programme being integrated into the regional primary health care programme. Wherever this approach is adopted, positive results are assured.

\section{PREVENTION WORK IN SOUTH AFRICA}

How does prevention work in South Africa compare with efforts elsewhere?

(1) Statistics: Industrially developed countries have a blindness rate of between, $05 \%$ and, $2 \%$. Any country having a blindness rate in excess of , $1 \%$ may be said to have a sizeable overburden of avoidable blindness. The South African National Council for the Blind bears knowledge of over 22000 blind people in this country, giving a favourable blindiness rate of less than . $1 \%$ Unfortunately, only minimum figures are obtained through a system of registration and the actual figure is certainly higher. Registration is a voluntary act and is often very difficult to effect. The elderly. in particular. neglect to register in the belief that no benefit is to be gained. It is probable that the incidence amongst the white population group closely parallels that in countries such as Britain and the United States, where the elderly blind predominate. The shortage of eye care facilities for the other population groups, especially the black group. may be responsible for a higher incidence. while a lesser life expectancy in the ir case may reduce the number of elderly blind people. Improved registration procedures and the use of sophisticated statistical methods would be necessary to achieve more accurate statistics.

(2) Primary health care: The application of the principles of primary health care in rural areas in South Africa is likely to effect a marked improvement in the general health of the population. It is imperative that eye care be considered an integral part of this programme and that the efforts of the South African National Council for the Blind, the ophthalmic profession, and public health authorities be better co-ordinated and produce closer teamwork. A lack of communication hinders progress.

(3) The use of mobile units: It is acknowledged that South Africa pioneered the use of mobile eye units in serving rural populations. South Africa has once again led the way by providing refraction as part of its mobile eye services. Regrettably, the dwindling number of ophthalmologists in South Africa and a lack of funds are severely limiting the efforts of the South African National Council for the Blind. Under such circumstances work needs to be concentrated in areas of greatest need and, particularly, in communities at risk. Further scientific surveys and a study of past reports of the Bureau for the Prevention of Blindness of the South African National Council for the Blind will help to determine priorities.

\section{IN CONCLUSION}

Sir John Wilson has said that the prevention of blindness depends upon a partnership between the blind of the world and the ophthalmologists. Let us affirm a similar partnership in South Africa. 